\title{
Fat Mass and Obesity-Associated Gene (FTO) in Eating Disorders: Evidence for Association of the rs9939609 Obesity Risk Allele with Bulimia nervosa and Anorexia nervosa
}

Timo D. Müllera, b, \# Brandon H. Greene ${ }^{c, \#} \quad$ Laura Bellodid $^{d}$ Maria C. Cavallini ${ }^{d}$ Elena Cellinie Daniela Di Bellad Stefan Ehrlich ${ }^{f}$ Stefano Erzegovesi ${ }^{d}$ Xavier Estivillg Fernando Fernández-Arandah ${ }^{\mathrm{h}}$ Manfred Fichter ${ }^{\mathrm{i}}$ Christian Fleischhaker ${ }^{j}$ Susann Scherag ${ }^{a}$ Monica Gratacòs ${ }^{g}$ Harald Grallert ${ }^{k}$ Beate Herpertz-Dahlmann' Wolfgang Herzog ${ }^{m}$ Thomas Illigk Ulrike Lehmkuhl $^{f}$ Benedetta Nacmias $^{e}$ Marta Ribasés ${ }^{g}$ Valdo Ricca $^{e}$ Helmut Schäfer ${ }^{c}$ André Scherag ${ }^{n}$ Sandro Sorbi ${ }^{e}$ Heinz-Erich Wichmann ${ }^{k}$ o Johannes Hebebrand ${ }^{a}$ Anke Hinney ${ }^{a}$

a Department of Child and Adolescent Psychiatry and Psychotherapy, University of Duisburg-Essen, Essen, ${ }^{b}$ Institute Diabetes and Obesity, German Research Center for Environmental Health, Helmholtz Zentrum München, Neuherberg, ' Institute of Medical Biometry and Epidemiology, Philipps-University, Marburg, Germany; ${ }^{d}$ Department of Neuropsychiatric Sciences (DSNP), Fondazione Centro S. Raffaele del Monte Tabor, Milan, e Department of Neurology and Psychiatric Sciences, University of Florence, Florence, Italy, ${ }^{f}$ Department of Child and Adolescent Psychiatry, Psychosomatics and Psychotherapy, Charité-Universitätsmedizin Berlin, Germany, ${ }^{9}$ Ciber en Epidemiología y Salud Pública (CIBERESP), Genes and Disease Programme, Center for Genomic Regulation (CRG-UPF), h CIBER Fisiopatologia Obesidad y Nutricion (CIBEROBN) and Department of Psychiatry, University Hospital of Bellvitge, L'Hospitalet de Llobregat, Barcelona, Spain, 'Department of Psychiatry, University of Munich, Munich, jDepartment of Child and Adolescent Psychiatry and Psychotherapy, University of Freiburg,

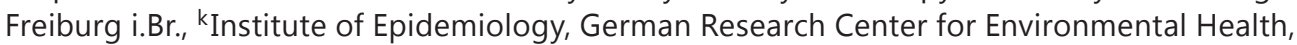
Helmholtz Zentrum München, Neuherberg, 'Department of Child and Adolescent Psychiatry and Psychotherapy, University Clinics, Technical University of Aachen, Aachen, ${ }^{m}$ Department of Internal Medicine II, General Internal and Psychosomatic Medicine, University of Heidelberg, Heidelberg, ${ }^{n}$ Institute of Medical Informatics, Biometry and Epidemiology, University of Duisburg-Essen, Essen, ${ }^{\circ}$ Institute of Medical Informatics, Biometry and Epidemiology, Chair of Epidemiology, Ludwig-Maximilians-Universität, Munich, Germany

\#Both authors contributed equally to this work. 


\title{
Key Words
}

Fat mass and obesity-associated gene $\cdot$ FTO $\cdot$ Eating disorders $\cdot$ Anorexia nervosa $\cdot$ Bulimia nervosa $\cdot$ Association study

\begin{abstract}
Objective: The common single nucleotide polymorphism (SNP) rs9939609 in the fat mass and obesity-associated gene (FTO) is associated with obesity. As genetic variants associated with weight regulation might also be implicated in the etiology of eating disorders, we evaluated whether SNP rs9939609 is associated with bulimia nervosa (BN) and anorexia nervosa (AN). Methods: Association of rs9939609 with BN and AN was assessed in 689 patients with AN, 477 patients with BN, 984 healthy non-population-based controls, and 3,951 populationbased controls (KORA-S4). Based on the familial and premorbid occurrence of obesity in patients with BN, we hypothesized an association of the obesity risk A-allele with BN. Results: In accordance with our hypothesis, we observed evidence for association of the rs9939609 A-allele with BN when compared to the non-population-based controls (unadjusted odds ratio $(O R)=1.142$, one-sided 95\% confidence interval $(C I) 1.001-\infty ;$ one-sided $p=0.049)$ and a trend in the population-based controls (OR $=1.124$, one-sided $95 \%$ CI 0.932- - ; one-sided $p=0.056)$. Interestingly, compared to both control groups, we further detected a nominal association of the rs9939609 A-allele to AN (OR $=1.181,95 \%$ CI 1.027-1.359, two-sided $p=0.020$ or $\mathrm{OR}=1.673,95 \% \mathrm{CI} 1.101-2.541$, two-sided $\mathrm{p}=0.015$, ). Conclusion: Our data suggest that the obesity-predisposing FTO allele might be relevant in both AN and BN.
\end{abstract}

Copyright (C) 2012 S. Karger GmbH, Freiburg

\section{Introduction}

Several SNPs in the first intron of the 'fat mass and obesity-associated' (FTO) gene are strongly associated with obesity in young individuals [1,2] and in adults [2-8]. The most frequently described SNP in FTO associated with obesity is rs9939609, which is located $82.431 \mathrm{~kb}$ downstream of ATG start codon of FTO. The association of rs 9939609 with obesity was discovered by a genome-wide association study (GWAS) for type 2 diabetes mellitus [3] and subsequently was convincingly corroborated by numerous other studies including the first GWAS for early onset (extreme) obesity [1]. Accordingly, since it was first described in 2007 [3], the obesity predisposing risk A-allele at rs9939609 has become one of the most solidly confirmed risk factors for polygenetic obesity worldwide [9]. Homozygous carriers of the risk A-allele at rs9939609 weigh about $3 \mathrm{~kg}$ more and have a 1.67-fold increased odds of obesity compared to homozygous carriers of the T-allele [3]. Whereas the association of rs9939609 with obesity is indisputable, uncertainty remains about the potential association of this variant with eating disorders such as anorexia nervosa (AN) $[10,11]$ and bulimia nervosa (BN). We and others have previously hypothesized that genes relevant in weight regulation might also be relevant in eating disorders [12-16]. Premorbid overweight and obesity are common in patients with BN, and a familial loading with obesity has also been described [17, 18]. In contrast, premorbid BMI in AN covers the whole BMI range [19], and a familial predisposition to obesity has not been reported. Accordingly, due to the frequently reported premorbid occurrence of obesity in patients with $\mathrm{BN}$, we hypothesized an association of the rs9939609 A-allele with BN, whereas for AN we had no specific a priori hypothesis. Additionally, we hypothesized that the obesity risk allele at rs9939609 is associated with maximum BMI-SDS in patients with these eating disorders. To determine whether the rs9939609 obesity risk-allele is associated with BN or AN, we analyzed a total of 6,101 individuals from three European countries (Germany, Italy, and Spain). 


\section{Material and Methods}

\section{Study Subjects}

The ascertainment strategy was previously described in detail [13, 20, 21]. Written informed consent was given by all participants and, in the case of minors, by their parents. All patients with eating disorders were diagnosed according to DSM-IV criteria [22]. The study was approved by the Ethics Committees of the Universities of Marburg, Duisburg-Essen, Heidelberg, Freiburg i.Br., Berlin, Aachen, Milan, Florence, and Barcelona as well as the Helmholtz Center Munich and carried out according to the Declaration of Helsinki.

In total, the study comprises 6,101 individuals from three European countries (Germany, Italy, and Spain). They were recruited at the Departments of Child and Adolescent Psychiatry of the Universities of Marburg, Duisburg-Essen, Aachen or Freiburg i.Br., Germany ( $\mathrm{N}=805)$; the Charité Hospital Berlin, Germany ( $\mathrm{N}=200)$; the German Research Center for Environmental Health, Helmholtz Center Munich, Neuherberg, Germany ( $\mathrm{N}=3,951)$, the Medical Psychosomatic Clinic Roseneck, Germany $(\mathrm{N}=90)$; the Department of Psychosomatic Medicine, University of Heidelberg, Germany $(\mathrm{N}=48)$, the Eating Disorders Unit of the Department of Psychiatry, University Hospital of Bellvitge, Spain ( $=503$ ); the Neurology Unit of the Department of Neurology and Psychiatric Sciences, University of Florence, Italy $(\mathrm{N}=232)$; or at the Fondazione Centro San Raffaelle del Monte Tabor, Milan, Italy (N =272). Anthropometric data of the study subjects are listed in table 1 .

The German samples included 103 patients with BN and 348 (10 male) patients with AN; of these 297 (6 male) individuals had acute AN, and 51 (4 male) were recovered individuals from two long-term follow-up studies of AN [23, 24]. The German controls included 692 non-population-based German normal-weight or lean healthy individuals. We chose to also include lean individuals as controls, as their BMI is similar to the BMI of patients with AN. Thus, a detected association should be attributable to AN rather than to low body weight. In this sample, all individuals with a current eating disorder, like AN or Eating Disorder not Otherwise Specified (EDNOS), as assessed by a short version of the Composite International Diagnostic Interview (CIDI), were excluded from the study. The CIDI questionnaire was kindly provided by Professor Wittchen. In addition, we further compared genotypes of AN and BN cases with a second control group that comprised of 3,935 individuals of a population-based cohort (Kooperative Gesundheitsforschung im Raum Augsburg, (KORA); i.e. Cooperative Health Research in the Region of Augsburg). The KORA sample is a representative study group of the population in the city and region of Augsburg (Bavaria, Germany) [25].

The Italian samples included 261 patients with AN and 243 patients with BN. Italian controls were not available. The Spanish samples included 80 patients with AN, 131 patients with BN, and 292 Spanish healthy non-population-based controls covering all weight categories (table 1). In total, the 689 patients with AN had a mean age of $21.83 \pm 7.13$ years and a mean BMI of $15.87 \pm 2.77 \mathrm{~kg} / \mathrm{m}^{2}$. The 477 patients with BN had a mean age of $25.10 \pm 6.51$ years and a mean BMI of $23.12 \pm 5.17 \mathrm{~kg} / \mathrm{m}^{2}$.

\section{Molecular and Genetic Methods}

Genotyping: The FTO SNP rs9939609 was either genotyped using ARMS-PCR as described previously [26], by KASPAR genotyping technology (KBioscience, Hoddesdon, UK), or (in case of the KORA samples) by MassARRAY system using iPLEX ${ }^{\mathrm{TM}}$ Gold chemistry (Sequenom, San Diego, CA, USA) [27]. PCR conditions and primer sequences can be obtained from the authors. For validity of genotypes, alleles were rated independently by at least two experienced individuals. Discrepancies were resolved unambiguously either by reaching consensus or by retyping. All missing calls (approximately $2 \%$ of all genotyped individuals) were successfully re-genotyped. To ensure validity of genotyping between the described methods, we genotyped rs9939609 twice in 93 individuals; the genotypes were identical.

\section{Statistics}

Hardy-Weinberg equilibrium for all independent study groups was tested with an exact test [28]. It is also noteworthy that the reported genotype and allele frequencies of SNP rs9939609 are very similar among samples of European origin, including those from Italy [3], Spain [29, 30] and Germany [1, 26]. As stratification is therefore negligible, previous studies for different phenotypes have assessed association of rs9939609 in combined samples of European origin [31, 32]. Accordingly, the case-control analyses reported here were also initially analyzed, irrespective of their origin; subsequent analyses were stratified by country (with the exception of the Italian cases due to a lack of controls from the same country). 
Müller et al.: Fat Mass and Obesity-Associated Gene (FTO) in Eating Disorders: Evidence for Association of the rs9939609 Obesity Risk Allele with Bulimia nervosa and Anorexia nervosa

Table 1. Anthropometric characteristics of study samples

\begin{tabular}{|c|c|c|c|c|c|}
\hline Group & Variable & German samples & & Italian samples & Spanish samples \\
\hline \multirow[t]{3}{*}{ AN } & $\mathrm{N}$ & $\begin{array}{l}297 \\
(6 \text { males })^{1}\end{array}$ & $\begin{array}{l}51 \\
(4 \text { males })^{2}\end{array}$ & 261 & 80 \\
\hline & age & $18.35 \pm 6.51$ & $\begin{array}{l}33.03 \pm 7.47^{3} \\
16.20 \pm 2.00^{4}\end{array}$ & $25.02 \pm 6.26$ & $24.03 \pm 6.19$ \\
\hline & BMI & $16.07 \pm 2.92$ & $\begin{array}{l}20.83 \pm 2.40^{5} \\
14.50 \pm 1.60^{6}\end{array}$ & $14.77 \pm 2.11$ & $16.97 \pm 1.91$ \\
\hline \multirow[t]{3}{*}{$\mathrm{BN}$} & $\mathrm{N}$ & 103 & & 243 & 131 \\
\hline & age & $24.28 \pm 7.10$ & & $25.10 \pm 6.50$ & $25.77 \pm 6.03$ \\
\hline & BMI & $22.80 \pm 6.65$ & & $22.40 \pm 4.20$ & $24.06 \pm 4.78$ \\
\hline \multirow[t]{3}{*}{ Controls } & $\mathrm{N}$ & $692^{7}$ & $3,951^{8}$ & & $292^{9}$ \\
\hline & age & $24.69 \pm 5.55$ & $49.16 \pm 13.89$ & & \\
\hline & $\mathrm{BMI}$ & $19.62 \pm 2.00$ & $27.22 \pm 4.72$ & & \\
\hline
\end{tabular}

${ }^{1}$ Acute patients with AN.

${ }^{2}$ Recovered patients with AN.

${ }^{3}$ Current age.

${ }^{4}$ Age of first admission.

${ }^{5} \mathrm{BMI}$ after recovery.

${ }^{6} \mathrm{BMI}$ at first admission.

${ }^{7}$ Non-population-based lean controls.

8Population-based controls.

${ }^{9}$ Spanish controls covering the whole BMI range.

This post-hoc stratification of the samples was performed after obtaining a nominally significant result at level $\alpha=0.05$ for the global test. The reasons for stratification were to explore the robustness of the association across subsamples and to analyze the association, as far as possible, in subsamples in which the possibility of population stratification is reduced. For this reason, odds ratio (OR) estimates and nominal p-values from each subsample are unadjusted for multiple testing and not intended to provide confirmatory evidence at the 0.05 significance level.

The maximum BMI-SDS values were calculated in both German children/adolescents and German adults for which maximum BMI values were available. The maximum lifetime BMI was assessed by standardized questionnaires upon patient assessment. The patients were asked for their highest lifetime body weight and the corresponding age. As we previously showed that body height does not alter considerably after 13 years of age [19], we used the measured height at referral for the maxixum BMI estimations. Based on the German age-related reference data $[33,34]$, the degree of maximum lifetime BMI was then quantified with Cole's least mean square method [35], which normalized the BMI taking gender and age into account, resulting in a standard deviation score (BMI-SDS).

For the case-control comparisons with regard to the obesity risk A-allele at rs9939609, we applied the Cochran-Armitage trend test and logistic regression without and with covariates BMI and age. For the outcome maximum BMI-SDS in BN and AN patients we applied Jonckheere's non-parametric trend test. We used a (log-)linear genetic model. Consistent with our unidirectional hypothesis that obesity is a risk factor for BN, we decided to display one-sided p-values for BN and two-sided p-values for AN in the casecontrol comparisons, whereas we reported one-sided p-values for the assessment of maximum BMI-SDS. All reported p-values are nominal and not adjusted for multiple testing, and we applied a level $\alpha=0.05$ for each test. 
For BN, 477 cases and 984 European non-population-based controls were estimated [36] to yield a power of $>0.80$ to detect a multiplicative genotype-relative risk (GRR) of 1.27 (assuming a minor allele frequency (MAF) of 0.4). For the comparison with the 3,951 population-based controls, power estimates were $>0.80$ for a multiplicative GRR of 1.24 (again assuming a MAF of 0.4). For AN, power estimates for 689 cases and 984 non-population-based controls were $>0.80$ for a multiplicative GRR of 1.24 and $>0.80$ for a multiplicative GRR of 1.20 compared to the 3,951 population-based controls (again assuming a MAF of 0.4 ).

\section{Results}

\section{Association of rs9939609 with BN}

The combined analysis of all patients with BN $(n=477)$ and all non-population-based controls $(n=984)$ revealed an association of the rs9939609 obesity risk-allele (A) with BN (the unadjusted effect size estimate for the risk allele was an OR of 1.142, one-sided 95\% confidence interval (CI) 1.001- $\infty$; one-sided $p=0.049,95 \%$; table 2). Even though not statistically significant, a similar trend was observed when comparing all patients with BN with the 3,951 individuals of the population-based KORA-S4 cohort (one-sided $p=0.056$; table 1 ). This trend did not change after exclusion of the 9 male subjects ( 468 cases and 3,951 controls; OR: 1.120 , one-sided 95\% CI 0.999- $-\infty$; $=0.052$, data not shown).

We also compared the patients with BN with the 3,951 population-based controls in a logistic regression model. In the case of BN, the unadjusted OR was 1.124 (one-sided 95\% CI 1.003- $\infty$; one-sided $\mathrm{p}=0.046$ ) and adjustment for age and BMI led to OR $=1.120$ (one-sided $95 \%$ CI 0.932- $\bullet$; one-sided $\mathrm{p}=0.155$ ). Thus, the results were similar to the initial association test based on the Cochran-Armitage trend test (one-sided $p=0.056$; table 2). The analyses stratified by country revealed that this observation was also consistent across subgroups with the exception of the German subgroup where no trend for differences in allele frequencies was observable (table 2).

In patients with BN we, however, observed no association of the obesity-predisposing risk A-allele at rs9939609 with BMI-SDS (TT $0.214 \pm 1.24$, TA $0.406 \pm 1.49$, AA $0.753 \pm$ 1.89; one-sided $\mathrm{p}=0.094$ ).

\section{Association of rs9939609 with AN}

In the case-control analysis including all patients with AN $(n=689)$ and all non-population-based controls $(\mathrm{n}=984)$, we unexpectedly observed a nominal association of the A-allele at rs9939609 with AN (unadjusted OR $=1.181,95 \%$ CI 1.027-1.359, two-sided p = 0.020 , table 3). This association was also seen after exclusion of all 29 male subjects (660 cases and 3,951 controls; OR: 1.176, 95\% CI 1.021-1.354; two-sided p $=0.025$; data not shown).

Again, we also compared the patients with AN with the 3,951 population-based individuals and observed an unadjusted OR $=1.176(95 \%$ CI 1.044-1.326; two-sided $\mathrm{p}=0.008)$ and age- and BMI-adjusted OR $=1.673(95 \%$ CI 1.101-2.541; two-sided $\mathrm{p}=0.016)$. Thus, the results for AN were also similar to the initial association test based on the Cochran-Armitage Test (two-sided $\mathrm{p}=0.015$; table 3 ). The stratified analyses revealed that this finding was robust across subsamples.

\section{Association of rs 9939609 with Maximum BMI-SDS in Eating Disorders}

The maximum BMI-SDS values were available for 105 German patients with BN and 214 German patients with AN. However, the trend test comparing the maximum BMI-SDS values revealed no evidence for an association of the rs 9939609 obesity risk A-allele with increased maximum BMI-SDS in patients with BN or AN (nominal $\mathrm{p}=0.066$ or $\mathrm{p}=0.180$; table 4 ). 
Müller et al.: Fat Mass and Obesity-Associated Gene (FTO) in Eating Disorders: Evidence for Association of the rs9939609 Obesity Risk Allele with Bulimia nervosa and Anorexia nervosa

Table 2. Case-control association studies in 477 patients with BN, 984 normal-weight and lean controls (European non-population-based controls) as well as 3,951 population-based controls for rs9939609 in the FTO

\begin{tabular}{|c|c|c|c|c|c|}
\hline Sample & $\mathrm{N}$ & $\begin{array}{l}\text { Genotypes } \mathrm{N}^{1} \\
\text { (frequency \%) }\end{array}$ & Alleles, \% & $\begin{array}{l}\text { HWE } \\
\text { p-value }\end{array}$ & $\mathrm{p}$-value ${ }^{2}$ \\
\hline All European BN cases & 477 & $\begin{array}{l}\text { TT: } 153(32.1) \\
\text { TA: } 235(49.3) \\
\text { AA: } 89(18.7)\end{array}$ & $\begin{array}{l}\mathrm{T}: 56.7 \\
\text { A: } 43.3\end{array}$ & 1.00 & \\
\hline European non-population-based controls & 984 & $\begin{array}{l}\text { TT: } 350(35.6) \\
\text { TA: } 479(48.6) \\
\text { AA: } 155(15.8)\end{array}$ & $\begin{array}{l}\text { T: } 59.9 \\
\text { A: } 40.1\end{array}$ & 0.742 & $0.049^{3}$ \\
\hline German population-based controls 5 & 3,951 & $\begin{array}{l}\text { TT: } 1,392(35.2) \\
\text { TA: } 1,909(48.3) \\
\text { AA: } 650(16.5)\end{array}$ & $\begin{array}{l}\text { T: } 59.4 \\
\text { A: } 40.6\end{array}$ & 0.947 & $0.056^{4}$ \\
\hline $\begin{array}{l}\text { Subsample } \\
\text { German BN cases }\end{array}$ & 103 & $\begin{array}{l}\text { TT: } 35(34.0) \\
\text { TA: } 55(53.4) \\
\text { AA: } 13(12.6)\end{array}$ & $\begin{array}{l}\text { T: } 60.7 \\
\text { A: } 39.3\end{array}$ & 0.302 & 0.546 \\
\hline $\begin{array}{l}\text { Subsample } \\
\text { German non-population-based controls }\end{array}$ & 692 & $\begin{array}{l}\text { TT: } 249(36.0) \\
\text { TA: } 336(48.6) \\
\text { AA: } 107(15.5)\end{array}$ & $\begin{array}{l}\text { T: } 60.3 \\
\text { A: } 39.7\end{array}$ & 0.751 & \\
\hline $\begin{array}{l}\text { Subsample } \\
\text { Italian BN cases }\end{array}$ & 243 & $\begin{array}{l}\text { TT: } 79(32.5) \\
\text { TA: } 117(48.1) \\
\text { AA: } 47(19.3)\end{array}$ & $\begin{array}{l}\text { T: } 56.6 \\
\text { A: } 43.4\end{array}$ & 0.794 & 0.091 \\
\hline $\begin{array}{l}\text { Subsample } \\
\text { European non-population-based controls }\end{array}$ & 984 & $\begin{array}{l}\text { TT: } 350(35.6) \\
\text { TA: } 479(48.6) \\
\text { AA: } 155(15.8)\end{array}$ & $\begin{array}{l}\text { T: } 59.9 \\
\text { A: } 40.1\end{array}$ & 0.691 & \\
\hline $\begin{array}{l}\text { Subsample } \\
\text { Spanish BN cases }\end{array}$ & 131 & $\begin{array}{l}\text { TT: } 39 \text { (29.8) } \\
\text { TA: } 63 \text { (48.1) } \\
\text { AA: } 29(22.1)\end{array}$ & $\begin{array}{l}\text { T: } 53.8 \\
\text { A: } 46.2\end{array}$ & 0.726 & 0.077 \\
\hline $\begin{array}{l}\text { Subsample } \\
\text { Spanish non-population-based controls }\end{array}$ & 292 & $\begin{array}{l}\text { TT: } 101(34.6) \\
\text { TA: } 143(49.0) \\
\text { AA: } 48(16.4)\end{array}$ & $\begin{array}{l}\text { T: } 59.1 \\
\text { A: } 40.9\end{array}$ & 0.904 & \\
\hline $\begin{array}{l}{ }^{1} \text { No evidence for deviations from Hardy } \\
{ }^{2} \text { One-sided uncorrected p-values. } \\
\text { 3Unadjusted estimated OR and } 95 \% \text { one } \\
{ }^{4} \text { Estimated OR and } 95 \% \text { one-sided CI } \\
\text { CI } 1.003-\infty \text { and OR } 1.124,95 \% \text { CI } 0.932-\infty \\
{ }^{5} \text { Note that in the } 3,951 \text { population-bas } \\
\text { risk A-allele for increased BMI (mean BMI } \\
\text { increase per A-allele } 0.3206 \pm 0.1085 p=0 \text {. }\end{array}$ & $\begin{array}{l}\text { Neinber } \\
\text { sided CI } \\
\text { h and } \mathrm{W} \\
\text { respecti } \\
\text { d contro } \\
\text { A: } 27.67 \\
32 \text { ). }\end{array}$ & $\begin{array}{l}\text { rg equilibrium }(\mathrm{p} \\
\text { I is: OR } 1.142,950 \\
\text { without adjustme } \\
\text { ively. } \\
\text { ols we also obser } \\
7 \pm 4.73 \text {, AT: } 27.2\end{array}$ & $\begin{array}{l}.05) \text {. } \\
\text { CI } 1.001-\infty \text {. } \\
\text { for age and } \\
\text { d an additiv } \\
4.75 \text {, TT: } 2\end{array}$ & $\begin{array}{l}\text { MI is: } 0 \\
\text { effect } 0 \\
.00 \pm 4.6\end{array}$ & $\begin{array}{l}1.120,95 \% \\
\text { the obesity } \\
\text {, mean BMI }\end{array}$ \\
\hline
\end{tabular}


Table 3. Case-control association studies in 689 patients with AN, 984 normal-weight and lean controls (European non-population-based controls) as well as 3,951 population-based controls for rs9939609 in the FTO

\begin{tabular}{|c|c|c|c|c|c|}
\hline Sample & $\mathrm{N}$ & 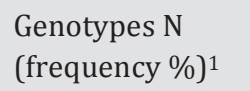 & Alleles,\% & $\begin{array}{l}\text { HWE } \\
\text { p-value }\end{array}$ & p-value ${ }^{2}$ \\
\hline All European AN cases & 689 & $\begin{array}{l}\text { TT: } 216(31.3) \\
\text { TA: } 338(49.1) \\
\text { AA: } 135(19.6)\end{array}$ & $\begin{array}{l}\text { T: } 55.9 \\
\text { A: } 44.1\end{array}$ & 0.9384 & \\
\hline European non-population-based controls & 984 & $\begin{array}{l}\text { TT: } 350(35.6) \\
\text { TA: } 479(48.6) \\
\text { AA: } 155(15.8)\end{array}$ & $\begin{array}{l}\text { T: } 59.9 \\
\text { A: } 40.1\end{array}$ & 0.691 & $0.020^{3}$ \\
\hline German population-based controls & 3,951 & $\begin{array}{l}\text { TT: } 1,392(35.2) \\
\text { TA: } 1,909(48.3) \\
\text { AA: } 650(16.5)\end{array}$ & $\begin{array}{l}\text { T: } 59.4 \\
\text { A: } 40.6\end{array}$ & 0.947 & $0.015^{4}$ \\
\hline German AN cases & 348 & $\begin{array}{l}\text { TT: } 117(33.6) \\
\text { TA: } 161(46.3) \\
\text { AA: } 70(20.1)\end{array}$ & $\begin{array}{l}\text { T: } 56.8 \\
\text { A: } 43.2\end{array}$ & 0.277 & 0.127 \\
\hline German non-population-based controls & 692 & $\begin{array}{l}\text { TT: } 249(36.0) \\
\text { TA: } 336(48.6) \\
\text { AA: } 107(15.5)\end{array}$ & $\begin{array}{l}\text { T: } 60.3 \\
\text { A: } 39.7\end{array}$ & 0.751 & \\
\hline Italian AN cases & 261 & $\begin{array}{l}\text { TT: } 79(30.3) \\
\text { TA: } 129(49.4) \\
\text { AA: } 53(20.3)\end{array}$ & $\begin{array}{l}\text { T: } 55.0 \\
\text { A: } 45.0\end{array}$ & 1.000 & 0.041 \\
\hline European non-population-based controls & 984 & $\begin{array}{l}\text { TT: } 350(35.6) \\
\text { TA: } 479(48.6) \\
\text { AA: } 155(15.8)\end{array}$ & $\begin{array}{l}\text { T: } 59.9 \\
\text { A: } 40.1\end{array}$ & 0.691 & \\
\hline Spanish AN cases & 80 & $\begin{array}{l}\text { TT: } 20(25.0) \\
\text { TA: } 48(60.0) \\
\text { AA: } 12(15.0)\end{array}$ & $\begin{array}{l}\text { T: } 55.0 \\
\text { A: } 45.0\end{array}$ & 0.074 & 0.341 \\
\hline Spanish non-population-based controls & 292 & $\begin{array}{l}\text { TT: } 101(34.6) \\
\text { TA: } 143(49.0) \\
\text { AA: } 48(16.4)\end{array}$ & $\begin{array}{l}\text { T: } 59.1 \\
\text { A: } 40.9\end{array}$ & 0.904 & \\
\hline $\begin{array}{l}{ }^{1} \text { No evidence for deviations from Hardy } \\
{ }^{2} \text { Two-sided uncorrected p-values. } \\
{ }^{3} \text { Estimated unadjusted OR and } 95 \% \mathrm{CI} \\
{ }^{4} \text { Estimated unadjusted and adjusted OF }\end{array}$ & $\begin{array}{l}\text { Neinb } \\
\text { e: OR } \\
\text { and } 95\end{array}$ & $\begin{array}{l}\text { g equilibrium ( } \\
\text { 180, 95\% CI } 1.0 \\
\text { CI are: OR } 1.17\end{array}$ & $\begin{array}{l}0.05) \\
-1.357 . \\
95 \% \text { CI } 1.0\end{array}$ & $4-1.326$ & OR 1.673; \\
\hline
\end{tabular}

\section{Discussion}

Genetic variation (e.g. at rs9939609) in the FTO has repeatedly been shown to be associated with obesity [1-8]. Based on our results we argue that the gene might also be relevant for eating disorders. Increased rates of both premorbid and familial overweight and obesity have been described in patients with BN $[17,18]$, whereas in patients with AN the premorbid BMI has been shown to cover the whole BMI distribution [37]. Hence, we had the a priori 
Table 4. Quantitative comparison of maximum BMI-SDS values in patients with AN or BN dependent on the rs9939609 genotype in the FTO

\begin{tabular}{lllll}
\hline Sample & Genotypes & $\mathrm{N}(\%)$ & Maximum BMI-SDS & p-value $^{1}$ \\
\hline AN + BN & TT & $95(29.8)$ & $0.758 \pm 1.290$ & 0.066 \\
& TA & $162(50.8)$ & $0.912 \pm 1.771$ & \\
& AA & $62(19.4)$ & $1.367 \pm 1.951$ & \\
\hline BN & TT & $33(31.4)$ & $1.405 \pm 1.496$ & 0.066 \\
& TA & $53(50.5)$ & $2.070 \pm 2.159$ & \\
& AA & $19(18.1)$ & $2.710 \pm 2.553$ & \\
AN & TT & $62(29.0)$ & $0.414 \pm 1.021$ & 0.180 \\
& TA & $109(50.9)$ & $0.348 \pm 1.206$ & \\
& AA & $43(20.1)$ & $0.772 \pm 1.248$ & \\
\hline
\end{tabular}

1Uncorrected p-value of the Jonckheere's non-parametric trend test. Note that the A-allele is the obesity risk allele.

directional hypothesis that the obesity risk allele is implicated in BN and tested accordingly. We observed a nominally significant association of the rs9939609 A-allele in 477 patients with BN compared to 984 non-population-based controls (one-sided $p=0.049$ ). For AN we had no specific a priori hypothesis. Nevertheless, for 689 patients with AN compared to 984 non-population-based controls we observed evidence for an association of the FTO obesity risk allele with AN (two-sided $p=0.020$ ). Eating disorders are typically characterized by diagnostic instability, migration between different subtypes, and even between different eating disorders $[38,39]$. However, whereas several studies consistently show that 25-30\% of patients with eating disorder migrate from $\mathrm{AN}$ to $\mathrm{BN}$, migration from $\mathrm{BN}$ to $\mathrm{AN}$ is less frequently described $[39,40]$. Therefore, it is unlikely that the observed association of the rs9939609 A-allele with AN can be explained by AN patients with a history of BN. However, one of the limitations of our study is that detailed amnesic information, especially regarding previous eating disorders as well as follow-up data, was not available. Furthermore, even though substantial evidence indicates that stratification is, due to the very similar allele frequencies of rs9939609 among Europeans [1, 3, 29, 30], negligible, the lack of Italian controls as well as the lack of anthropometric characteristics for the Spanish controls are other limitations of this study. Noteworthy, excluding the 243 Italian BN cases from our analysis (and thus decreasing the sample size by $49.1 \%$ from 477 to 234 patients with BN) would yield a nominal one-sided p-value of 0.110 for the comparison of the remaining 234 European BN cases versus 984 non-population based controls (OR 1.137, one-sided 95\% CI $0.957-\infty$ ) and a nominal one-sided p-value of 0.137 for the comparison with the 3,951 German population-based controls (OR 1.111, one-sided 95\% CI 0.948- $\infty$ ). Exclusion of the 261 Italian patients with AN (and thus decreasing the sample size by 37.9\% from 689 to 428 patients with AN) would yield a nominal two-sided p-value of 0.083 for the comparison of the remaining 428 patients with AN versus the 984 European non-population based controls (OR 1.155; 95\% CI 0.981-1.360) and a nominal two-sided p-value of 0.094 for the comparison with the 3,951 German population-based controls. As solid evidence indicates that there are no stratification effects of rs9939609 among samples from Italy, Spain and Germany, the observed loss of significance is likely to be attributable to the dramatic loss of statistical power. Accordingly, to maximize the statistical power we choose to keep the Italian samples in our analysis. However, further studies are warranted to independently confirm our results and to analyze if, and to what extent, the association of the FTO risk allele is dependent 
on the DSM-IV AN and BN subtypes and the transversion of AN into BN (and vice versa). Another interesting aspect is the possible confounding effect of the behavioral influences on BMI in AN and BN patients. Since low BMI possibly influenced by FTO alleles will make individuals with eating disorders more likely to be diagnosed and become cases, this could be one potential source of confounding due to BMI in our analyses.

Besides a recent publication on the absence of an association of genetic variation in FTO in a sample of 267 patients with AN and 1,636 population-based controls [10], three studies investigated the effect of FTOvariants on eating behavior [41-43]. Whereas, after adjustment for age and BMI, no association was found between rs9939609 and energy expenditure [41], two studies indicated a BMI-independent association of the rs9939609 risk A-allele with increased energy intake [41, 42] and decreased satiety [43]. Similarly, our observed association of FTO with AN might be independent of the elevating effect of this variant on BMI as based on our regression analysis including BMI as a quantitative covariate. Alternatively, it is possible that both a weight-elevating effect of the risk A-allele and a modulation of eating behavior and satiety accounts for the observed associations. Noteworthy, a recent publication further reports no association of FTO variants with psychological and behavioral eating disorder phenotypes, such as anxiety, harm avoidance, novelty seeking, impulsivity, obsessionality, compulsivity, and concern over mistakes [11].

A subgroup of the German non-population-based controls was lean (BMI below the 15th BMI percentile) and might thus have biased our analyses due to the established association of rs9939609 with obesity. Hence, we added a comparison of AN and BN cases with 3,951 individuals of a German population-based cohort (KORA) and adjusted for BMI and age. These analyses supported the aforementioned findings. It is further noteworthy that within the 3,951 population-based controls we also observed a significant additive effect of the obesity risk A-allele for an increased BMI (mean BMI AA $27.67 \pm 4.73$, AT $27.25 \pm 4.75$ TT $27.00 \pm 4.65$, mean BMI increase per A-allele $0.321 \pm 0.109 ; p=0.0032)$. Noteworthy, this trend was robust after adjustment for age and gender (mean increase per A-allele $0.329 \pm$ 0.104; $\mathrm{p}=0.0016$ ).

We also hypothesized that the risk allele (A) for obesity at rs9939609 is associated with maximum BMI-SDS in patients with BN or AN. Analyses of maximum BMI-SDS values of individuals carrying either one, two, or no risk A-allele at rs9939609 revealed, however, no association of the obesity risk A-allele with maximum BMI-SDS in patients with either BN or AN (one-sided $\mathrm{p}=0.066$ or 0.180 ).

In summary, we observed evidence for an association of the A-allele at rs9939609 with both $\mathrm{AN}$ and BN. In patients with AN, the association was robust after adjustment for BMI and age. While the observation for AN was unexpected, the observed association of the obesity-predisposing risk A-allele with $\mathrm{BN}$ is in line with previous findings $[17,18]$. As obesity is a risk factor for the development of $\mathrm{BN}$, obesity risk alleles should be more frequent in patients with BN. We conclude that genetic variation in FTO might be implicated in the etiology of BN and AN. However, additional research is warranted to determine whether the risk allele has a direct, indirect, or synergistic effect on eating disorders. The trend observed for association with maximum BMI-SDS in patients with BN suggests that for this eating disorder the association is indirect or synergistic. To address this question, we also analyzed the effect of FTO alleles on BN after adjusting for age and maximum BMI. The caveat of this approach is, however, that many of the lean controls were recruited for low current BMI which is strongly correlated with the maximum BMI of these patients. To control for this bias we adjusted our data for current BMI, revealing a nonsignificant estimated effect from the FTO risk A-allele (OR 0.888, 95\% CI 0.601-1.312; $\mathrm{p}=0.552$ ) and a significant effect from max BMI (OR 2.134, 95\% CI: 1.779-2.560; p < 0.001), thus identifying that the effect of FTO on $\mathrm{BN}$ is indeed indirect. 


\section{Acknowledgments}

This work was supported by grants from the German Federal Ministry of Education and Research (01KU0903 and 01GI0823, 01GV0623, 01GV060, 01GV0624, 01GV0602, 01GV0905; NGFN2: 01GS0482, 01GS0483; NGFN ${ }^{\text {Plus: }}$ 01GS0820), the European Union (FP6 LSHMCT-2003-503041), the Deutsche Forschungsgemeinschaft (DFG; HE 1446/4-1), the Spanish Ministry of Education and Science (SAF2005-01005), the 'Fondo de Investigaciones Sanitarias de la Seguridad Social, FIS (PI040632; PI081714), the Department of Health (Generalitat de Catalunya), CIBER is an initiative of ISCIII (Spain), the Department of Universities, Research and Information Society (2005SGR00008; 2009SGR 1554) (Generalitat de Catalunya), the Company of San Paolo (Grant No. 2007.0992 awarded to B. Nacmias), the University of Florence (Indagine genetica e studio dei fattori di rischio associati ai disturbi del comportamento alimentare : NACMATEN09), and by the Hilda and Preston Davis Foundation - Davis Foundation Postdoctoral Fellowship Program in Eating Disorders. The KORA research platform was initiated and financed by the Helmholtz Center Munich, German Research Center for Environmental Health, which is funded by the German Federal Ministry of Education and Research and by the State of Bavaria. We thank all patients for their participation. The skillful technical assistance of Jitka Andrae and Sieglinde Düerkop is highly appreciated.

\section{Disclosure Statement}

The authors declare that there is no conflict of interest.

\section{References}

1 Hinney A, Nguyen TT, Scherag A, Friedel S, Brönner G, Müller TD, Grallert H, Illig T, Wichmann HE, Rief W, Schäfer H, Hebebrand J: Genome wide association (GWA) study for early onset extreme obesity supports the role of fat mass and obesity associated gene (FTO) variants. PLoS ONE 2007;2:e1361.

2 Dina C, Meyre D, Gallina S, Durand E, Körner A, Jacobson P, Carlsson LM, Kiess W, Vatin V, Lecoeur C, Delplanque J, Vaillant E, Pattou F, Ruiz J, Weill J, Levy-Marchal C, Horber F, Potoczna N, Hercberg S, Le Stunff C, Bougnères P, Kovacs P, Marre M, Balkau B, Cauchi S, Chèvre JC, Froguel P: Variation in FTO contributes to childhood obesity and severe adult obesity. Nat Genet 2007;39:724-726.

3 Frayling TM, Timpson NJ, Weedon MN, Zeggini E, Freathy RM, Lindgren CM, Perry JR, Elliott KS, Lango H, Rayner NW, Shields B, Harries LW, Barrett JC, Ellard S, Groves CJ, Knight B, Patch AM, Ness AR, Ebrahim S, Lawlor DA, Ring SM, Ben-Shlomo Y, Jarvelin MR, Sovio U, Bennett AJ, Melzer D, Ferrucci L, Loos RJ, Barroso I, Wareham NJ, Karpe F, Owen KR, Cardon LR, Walker M, Hitman GA, Palmer CN, Doney AS, Morris AD, Smith GD, Hattersley AT, McCarthy MI: A common variant in the FTO gene is associated with body mass index and predisposes to childhood and adult obesity. Science 2007;316:889-894.

4 Scuteri A, Sanna S, Chen WM, Uda M, Albai G, Strait J, Najjar S, Nagaraja R, Orrú M, Usala G, Dei M, Lai S, Maschio A, Busonero F, Mulas A, Ehret GB, Fink AA, Weder AB, Cooper RS, Galan P, Chakravarti A, Schlessinger D, Cao A, Lakatta E, Abecasis GR: Genome-wide association scan shows genetic variants in the FTO gene are associated with obesity-related traits. PLoS Genet 2007;3:e115.

- 5 Hunt SC, Stone S, Xin Y, Scherer CA, Magness CL, Ladonato SP, Hopkins PN, Adams TD: Association of the FTO gene with BMI. Obesity (Silver Spring) 2008;16:902-904.

- 6 Kring SI, Holst C, Zimmermann E, Jess T, Berentzen T, Toubro S, Hansen T, Astrup A, Pedersen O, Sørensen TI: FTO gene associated fatness in relation to body fat distribution and metabolic traits throughout a broad range of fatness. PLoS ONE 2008;3:e2958.

7 Chang YC, Liu PH, Lee WJ, Chang TJ, Jiang YD, Li HY, Kuo SS, Lee KC, Chuang LM: Common variation in the fat mass and obesity-associated (FTO) gene confers risk of obesity and modulates BMI in the Chinese population. Diabetes 2008;57:2245-2252.

8 Hotta K, Nakata Y, Matsuo T, Kamohara S, Kotani K, Komatsu R, Itoh N, Mineo I, Wada J, Masuzaki H, Yoneda M, Nakajima A, Miyazaki S, Tokunaga K, Kawamoto M, Funahashi T, Hamaguchi K, Yamada K, Hanafusa T, Oikawa S, Yoshimatsu H, Nakao K, Sakata T, Matsuzawa Y, Tanaka K, Kamatani N, Nakamura Y: Variations in the FTO gene are associated with severe obesity in the Japanese. J Hum Genet 2008;53:546-553.

9 Peng S, Zhu Y, Xu F, Ren X, Li X, Lai M: FTO gene polymorphisms and obesity risk: a meta-analysis. BMC Med 2011,9:71.

10 Brandys MK, van Elburg AA, Loos RJ, Bauer F, Hendriks J, van der Schouw YT, Adan RA: Are recently identified genetic variants regulating BMI in the general population associated with anorexia nervosa? Am J Med Genet B Neuropsychiatr Genet 2009;153B:695-699. 
11 Jonassaint CR, Szatkiewicz JP, Bulik CM, Thornton LM, Bloss C, Berrettini WH, Kaye WH, Bergen AW, Magistretti P, Strober M, Keel PK, Brandt H, Crawford S, Crow S, Fichter MM, Goldman D, Halmi KA, Johnson C, Kaplan AS, Klump KL, La Via M, Mitchell JE, Rotondo A, Treasure J, Woodside DB: Absence of association between specific common variants of the obesity-related FTO gene and psychological and behavioral eating disorder phenotypes. Am J Med Genet B Neuropsychiatr Genet 2011;156:454-461.

$\checkmark 12$ Hinney A, Friedel S, Remschmidt H, Hebebrand J: Genetic risk factors in eating disorders. Am J Pharmacogenomics 2004;4:209-223.

13 Hinney A, Bettecken T, Tarnow P, Brumm H, Reichwald K, Lichtner P, Scherag A, Nguyen TT, Schlumberger P, Rief W, Vollmert C, Illig T, Wichmann HE, Schäfer H, Platzer M, Biebermann H, Meitinger T, Hebebrand J: Prevalence, spectrum, and functional characterization of melanocortin-4 receptor gene mutations in a representative population-based sample and obese adults from Germany. J Clin Endocrinol Metab 2006;91: 1761-1769.

14 Day J, Ternouth A, Collier DA: Eating disorders and obesity: two sides of the same coin? Epidemiol Psichiatr 2009;18:96-100.

15 Pinheiro AP, Sullivan PF, Bacaltchuck J, Prado-Lima PA, Bulik CM: Genetics in eating disorders: extending the boundaries of research. Rev Bras Psiquiatr 2006;28:218-225.

16 Hebebrand J, Remschmidt H: Anorexia nervosa viewed as an extreme weight condition: genetic implications. Hum Genet 1995;95:1-11.

17 Fairburn CG, Harrison PJ: Eating disorders. Lancet 2003;361:407-416.

18 Nishimura H, Komaki G, Ando T, Nakahara T, Oka T, Kawai K, Nagata T, Nishizono A, Okamoto Y, Okabe K, Koide M, Yamaguchi C, Saito S, Ohkuma K, Nagata K, Naruo T, Takii M, Kiriike N, Ishikawa T; Japanese Genetic Research Group for Eating Disorders: Psychological and weight-related characteristics of patients with anorexia nervosa-restricting type who later develop bulimia nervosa. Biopsychosoc Med 2008;2:5.

19 Coners H, Remschmidt H, Hebebrand J: The relationship between premorbid body weight, weight loss, and weight at referral in adolescent patients with anorexia nervosa. Int J Eat Disord 1999;26:171-178.

-20 Cellini E, Nacmias B, Brecelj-Anderluh M, Badía-Casanovas A, Bellodi L, Boni C, Di Bella D, Estivill X, Fernandez-Aranda F, Foulon C, Friedel S, Gabrovsek M, Gorwood P, Gratacos M, Guelfi J, Hebebrand J, Hinney A, Holliday J, Hu X, Karwautz A, Kipman A, Komel R, Rotella CM, Ribases M, Ricca V, Romo L, Tomori M, Treasure J, Wagner G, Collier DA, Sorbi S; EC Framework V 'Factors in Healthy Eating' consortium: Casecontrol and combined family trios analysis of three polymorphisms in the ghrelin gene in European patients with anorexia and bulimia nervosa. Psychiatr Genet 2006;16:51-52.

-21 Ribasés M, Gratacòs M, Fernández-Aranda F, Bellodi L, Boni C, Anderluh, Cristina Cavallini M, Cellini E, Di Bella D, Erzegovesi S, Foulon C, Gabrovsek M, Gorwood P, Hebebrand J, Hinney A, Holliday J, Hu X, Karwautz A, Kipman A, Komel R, Nacmias B, Remschmidt H, Ricca V, Sorbi S, Tomori M, Wagner G, Treasure J, Collier DA, Estivill X: Association of BDNF with restricting anorexia nervosa and minimum body mass index: a family-based association study of eight European populations. Eur J Hum Genet 2005;13:428-434.

22 American Psychiatric Association: Diagnostic and Statistical Manual, 4th ed. Washington, DC, American Psychiatric Association, 1995.

23 Herpertz-Dahlmann B, Müller B, Herpertz S, Heussen N, Hebebrand J, Remschmidt H: Prospective 10-year follow-up in adolescent anorexia nervosa-course, outcome, psychiatric comorbidity, and psychosocial adaptation. J Child Psychol Psychiatry 2001;42:603-612.

24 Herpertz-Dahlmann BM, Wewetzer C, Schulz E, Remschmidt H: Course and outcome in adolescent anorexia nervosa. Int J Eat Disord 1996;19:335-345.

25 Wichmann HE, Gieger C, Illig T: KORA-gen-resource for population genetics, controls and a broad spectrum of disease phenotypes. Gesundheitswesen 2005;67(suppl 1):S26-30.

26 Müller TD, Hinney A, Scherag A, Nguyen TT, Schreiner F, Schaefer H, Hebebrand J, Roth CL, Reinehr T: 'Fat mass and obesity associated' gene (FTO): no significant association of variant rs 9939609 with weight loss in a lifestyle intervention and lipid metabolism markers in German obese children and adolescents. BMC Med Genet 2008;9:85.

-27 Herder C, Rathmann W, Strassburger K, Finner H, Grallert H, Huth C, Meisinger C, Gieger C, Martin S, Giani G, Scherbaum WA, Wichmann HE, Illig T: Variants of the PPARG, IGF2BP2, CDKAL1, HHEX, and TCF7L2 genes confer risk of type 2 diabetes independently of BMI in the German KORA studies. Horm Metab Res 2008;40:722-726.

28 Wigginton E, Cutler D, Abecasis G: A Note on exact tests of Hardy-Weinberg equilibrium. Am J Hum Genet 2005;76:887-883.

29 López-Bermejo A, Petry CJ, Díaz M, Sebastiani G, de Zegher F, Dunger DB, Ibáñez L: The association between the FTO gene and fat mass in humans develops by the postnatal age of two weeks. J Clin Endocrinol Metab 2008;93:1501-1505.

30 Corella D, Carrasco P, Sorlí JV, Coltell O, Ortega-Azorín C, Guillén M, González JI, Sáiz C, Estruch R, Ordovas JM: Education modulates the association of the FTO rs 9939609 polymorphism with body mass index and obesity risk in the Mediterranean population. Nutr Metab Cardiovasc Dis 2010; doi: 10.1016/j. numecd.2010.10.006. 
Müller et al.: Fat Mass and Obesity-Associated Gene (FTO) in Eating Disorders: Evidence for Association of the rs9939609 Obesity Risk Allele with Bulimia nervosa and Anorexia nervosa

-31 Labayen I, Ruiz JR, Ortega FB, Dalongeville J, Jiménez-Pavón D, Castillo MJ, De Henauw S, González-Gross M, Bueno G, Molnar D, Kafatos A, Díaz LE, Meirhaeghe A, Moreno LA: Association between the FTO rs9939609 polymorphism and leptin in European adolescents: a possible link with energy balance control. The HELENA study. Int J Obes (Lond) 2011;35:66-71

32 Ruiz JR, Labayen I, Ortega FB, Legry V, Moreno LA, Dallongeville J, Martínez-Gómez D, Bokor S, Manios Y, Ciarapica D, Gottrand F, De Henauw S, Molnár D, Sjöström M, Meirhaeghe A; HELENA Study Group: Attenuation of the effect of the FTO rs 9939609 polymorphism on total and central body fat by physical activity in adolescents: the HELENA study. Arch Pediatr Adolesc Med 2010;164:328-333.

33 Anders HJ, Rosenbauer J, Matiaske B: Repäsentative Verzehrstudie in der Bundesrepublik Deutschland inkl. West-Berlin. Zeitschriftenreihe der AGEV 1990, Bd. 8. Umschau Verlag, Frankfurt.

34 Hebebrand J, Heseker H, Himmelmann GW, Schäfer H, Remschmidt H: Percentiles for the body mass index based on data of the German National Nutrition Survey and a review of relevant factors with an influence on body weight. Akt Ernährungsmed 1994;19:259-265.

-35 Kromeyer-Hauschild K, Wabitsch M, Kunze D, Geller F, Geiß HC, Hesse V, von Hippel A, Jaeger U, Johnson D, Kiess W, Korte W, Kunze D, Menner K, Muller M, Niemann-Pilatus A, Remer T, Schaefer F, Wittchen HU, Zabransky S, Zellner K, Hebebrand J: Perzentilen für den Body Mass Index für das Kindes- und Jugendalter unter Heranziehung verschiedener deutscher Stichproben. Monatsschr Kinderheilkd 2001;149:807-818.

-36 Slager SL, Schaid DJ: Case-control studies of genetic markers: power and sample size approximations for Armitage's test for trend. Hum Hered 2001;52:149-153.

37 Holtkamp K, Mogharrebi R, Hanisch C, Schumpelick V, Herpertz-Dahlmann B: Gastric dilatation in a girl with former obesity and atypical anorexia nervosa. Int J Eat Disord 2002;32:372-376.

- 38 Milos G, Spindler A, Schnyder U, Fairburn CG: Instability of eating disorder diagnoses: prospective study. Br J Psychiatry 2005;187:573-578.

-39 Tozzi F, Thornton LM, Klump KL, Fichter MM, Halmi KA, Kaplan AS, Keel P, Klump KL, Lilenfeld LR, Mitchell JE, Plotnicov KH, Pollice C, Rotondo A, Strober M, Woodside DB, Berrettini WH, Kaye WH, Bulik CM: Symptom fluctuation in eating disorders: correlates of diagnostic crossover. Am J Psychiatry 2005;162: 732-740.

40 Gorwood P, Kipman A, Foulon C: The human genetics of anorexia nervosa. Eur J Pharmacol 2003;480:163170.

-41 Cecil JE, Tavendale R, Watt P, Hetherington MM, Palmer CN: An obesity-associated FTO gene variant and increased energy intake in children. N Engl J Med 2008;359:2558-2566.

-42 Wardle J, Llewellyn C, Sanderson S, Plomin R: The FTO gene and measured food intake in children. Int J Obes (Lond) 2009;33:42-45.

43 Wardle J, Carnell S, Haworth CM, Farooqi IS, O’Rahilly S, Plomin R: Obesity associated genetic variation in FTO is associated with diminished satiety. J Clin Endocrinol Metab 2009;93:3640-3643. 